\title{
O TRIBUNAL DE NUREMBERG E A TEORIA PURA DO DIREITO
}

\author{
THE NUREMBERG TRIALS AND THE PURE THEORY OF LAW
}

\section{LOS JUICIOS DE NÚREMBERG Y LA TEORÍA PURA DEL DERECHO}

\author{
RICARDO BORRMANN \\ https://orcid.org/0000-0003-4541-6360 / http:// lattes.cnpq.br/5405956726894705 / rborrmann@uni-bremen.de \\ Universidade de Bremen, Alemanha.
}

https: / /orcid.org/0000-0003-2430-8723 /http://lattes.cnpq.br/8371246022549504 / eugeniuszcruz@gmail.com

EUGENIUSZ CRUZ Universidade Federal Fluminense (UFF)

\begin{abstract}
RESUMO
Este ensaio aborda o panorama histórico em que se desenvolveram duas teorias que viabilizaram, no contexto do direito internacional, a responsabilização pelas violações de direitos humanos ocorridas durante a Segunda Guerra Mundial. A análise focaliza (I) a Teoria Pura do Direito (TPD) de Hans Kelsen e (II) a "Fórmula de Radbruch", problematizando a acusação ao positivismo jurídico de que este compactuou com o regime nazista, deixando os juízes alemães de "mãos atadas". A hipótese é a de que o vínculo do positivismo de Kelsen com os crimes cometidos pelo regime nazista não encontra sustentação (I) nem no processo histórico, portanto, em fatores externos à sua teoria, ligados ao percurso intelectual de Hans Kelsen como jurista e teórico do Direito, (II) nem nos pressupostos de sua TPD. 0 estudo analisa ainda os processos de Nuremberg em sua conjuntura histórica, a adequação das críticas de Radbruch ao positivismo kelseniano, bem como as críticas de Kelsen ao Tribunal de Nuremberg.
\end{abstract}

Palavras-chave: direito internacional; direitos humanos; Teoria Pura do Direito; Fórmula de Radbruch; Tribunal de Nuremberg

\begin{abstract}
This essay approaches the historic context in which two theories have developed and enabled the judicial accountability for the violations of human rights occurred during the Second World War. The analysis focuses (I) on Hans Kelsen's the Pure Theory of Law (PTL) and (II) on "Radbruch's Formula", addressing the accusations that the legal positivism colluded with the Nazi regime, leaving the German judges "powerless". The hypothesis is that the link between Kelsen's positivism and the crimes committed by the Nazi regime does not find support neither (I) in the historical process, therefore in the external elements of Kelsen's Theory, related to his intellectual life, nor (II) in the fundaments of his PTL. Furthermore, this study analyses the Nuremberg Trials in their historical conjuncture, as well as Radbruch's critiques to Kelsen's legal positivism and the latter's critiques to the Trials of Nuremberg.
\end{abstract}

Keywords: international law; human rights; Pure Theory of Law; Radbruch’s Formula; Nuremberg Trials

\section{RESUMEN}

Este artículo aborda el panorama histórico en el que se desarrollaron dos teorías que viabilizaron, en el contexto del derecho internacional, la responsabilización por las violaciones de derechos humanos ocurridas durante la Segunda Guerra Mundial. El análisis se centra en (I) la Teoría Pura del Derecho (TPD) de Hans Kelsen y (II) la "Fórmula de Radbruch", abordando las acusaciones de que el positivismo jurídico coludió con el régimen nazi, dejando a los jueces alemanes de "manos atadas". La hipótesis es que el vínculo del positivismo de Kelsen con los crímenes cometidos por el régimen nazi no se sustenta (I) ni en el proceso histórico, por lo tanto, en factores externos a su teoría, relacionados a la trayectoria intelectual de Hans Kelsen como jurista y teórico del derecho, (II) ni en los presupuestos de su TPD. El estudio también analiza a los procesos de Núremberg en su contexto histórico, la adecuación de las críticas de Radbruch al positivismo de Kelsen, así como las críticas de Kelsen a los Juicios de Núremberg.

Palabras clave: derecho internacional; derechos humanos; Teoría Pura del Derecho; Fórmula de Radbruch; Juicios de Núremberg 


\section{SUMÁRIO}

INTRODUÇÃO; 1 A TPD E O CONTEXTO HISTÓRICO DE ASCENSÃO DO NAZISMO; 2 AS CRÍTICAS DE RADBRUCH AO POSITIVISMO KELSENIANO; 3 O TRIBUNAL DE NUREMBERG E AS VIOLAÇÕES DE DIREITOS HUMANOS; 5 A “FÓRMULA DE RADBRUCH" E AS CRÍTICAS DE KELSEN AOS PROCESSOS DE NUREMBERG; CONCLUSÃO; REFERÊNCIAS.

\section{INTRODUÇÃO}

0 presente artigo insere-se nos estudos interdisciplinares articulados aos campos da história do direito e da teoria política, e teve como ponto de partida as discussões realizadas no âmbito do Laboratório Cidade e Poder, da Universidade Federal Fluminense (LCP/UFF). Este ensaio tem como propósito investigar o contexto histórico em que se desenvolveram duas teorias centrais no cenário jurídico internacional do pós Segunda Guerra Mundial no que tange à responsabilização (accountability) pela violação de direitos fundamentais. Analisar-se-á, portanto, a conjuntura em que foram recepcionadas (I) a Teoria Pura do Direito (TPD) de Hans Kelsen e (II) a "Fórmula de Radbruch".

A “Fórmula de Radbruch" partiu do pressuposto de reconsiderar o papel da justiça em seu conceito de direito, especialmente após a traumática experiência nazista, e foi utilizada para fundamentar casos em que o direito contraria as exigências da justiça. Por outro lado, de acordo com o entendimento corrente sobre a TPD no Brasil, a teoria de Kelsen se filiaria à tese positivista de que a ilegitimidade moral não implica na invalidade jurídica da norma, uma vez que a moralidade não integraria o direito, de modo que qualquer conteúdo poderia ser jurídico. ${ }^{1}$ Pretende-se sinalizar para fatores históricos e teóricos que questionam essas críticas à TPD.

A tese de Radbruch foi absorvida para fundamentar os processos criminais considerados como precursores para a construção do que contemporaneamente se compreende como crimes contra a humanidade. A proposição foi aplicada na Alemanha após a derrota do regime nazista,

\footnotetext{
1 "Quando o direito se apresenta como um elemento da moral, isso se torna obscuro, se significar uma exigência natural para que o direito seja apresentado como moral, ou, se isso significar que o direito, como parte integrante da moral, possui um caráter efetivamente moral, tenta-se atribuir um valor absoluto ao direito, levando-se em conta a moral”. Cf. KELSEN, Hans. Teoria Pura do Direito. 9. ed. revista da tradução de J. Cretella Jr. e Agnes Cretella. São Paulo: Revista dos Tribunais, 2013, p. 77-78.
} 


\section{UDIREITO}

O TRIBUNAL DE NUREMBERG E A TEORIA PURA DO DIREITO

nos processos do Tribunal de Nuremberg, realizados entre 20 de novembro de 1945 e $1^{\circ}$ de outubro de $1946^{2}$. O tema foi crucial no contexto histórico de reconstrução da Alemanha.

A hipótese que este trabalho apresenta é a de que a conexão do positivismo de Kelsen com os crimes cometidos pelo regime nazista não encontra sustentação (I) nem nos elementos históricos, externos à sua teoria portanto, ligados à trajetória de Kelsen como jurista e teórico do direito, (II) nem nos pressupostos de sua TPD. Assim, argumenta-se que a relação entre o positivismo de Kelsen e os crimes do regime nazista resulta de uma incompreensão de sua obra. A defesa dos acusados pelos crimes praticados entre 1933-1945 argumentou que eles estavam agindo no estrito cumprimento de normas legais ${ }^{3}$ emitidas por seus superiores ou pelo seu líder político. A crítica à obra de Kelsen baseou-se em parte neste argumento da defesa.

O foco adotado está, portanto, na discussão sobre os fundamentos jurídicos que justificaram os julgamentos das violações de direitos humanos ocorridas durante a Segunda Guerra Mundial. Diante desse panorama, sugere-se uma investigação histórica que visa compreender os pressupostos que respaldaram as práticas do regime nazista ${ }^{4}$, bem como os princípios evocados para justificar os ataques aos judeus ${ }^{5}$, a busca pela expansão territorial com a imposição de uma ideologia de domínio, e a tendência à dilatação do poder político executivo.

Este ensaio investiga se as críticas feitas à TPD estão ou não amparadas pela história social e pelos pressupostos jurídicos da referida teoria. Para tanto, analisar-se-á os seguintes fatores: (I) o contexto histórico em que se formulou a TPD e os objetivos que orientaram a sua elaboração. Aqui será de fundamental importância o debate teórico entre Kelsen e outro jurista

\footnotetext{
${ }^{2}$ Neste artigo analisar-se-á somente os processos de Nuremberg contra os principais criminosos de guerra, ocorridos sob o Tribunal Militar Internacional segundo Estatuto de Londres (ou a Carta de Nuremberg), conduzido pelas principais potenciais vencedores da Segunda Guerra Mundial - Grã-Bretanha, Estados Unidos, França e União Soviética. Não será objeto de análise aqui os casos subsequentes, conduzidos entre 9 de dezembro de 1946 e 14 de abril de 1949 na mesma cidade de Nuremberg pelos Estados Unidos através de seu Office of the US Chief of Counsel for War Crimes (OCCWC). Sobre a discussão se estes processos merecem o nome de processos subsequentes de Nuremberg e a contribuição da União Soviética no Tribunal de Nuremberg, ver SCHULMEISTER-ANDRÉ, Irina. Internationale Strafgerichtsbarkeit unter sowjetischem Einfluss. Der Beitrag der UdSSR zum Nürnberger Hauptkriegsverbrecherprozess. Berlin: Duncker \& Humboldt, 2016.

${ }^{3}$ Cf. ARENDT, Hannah. Eichmann em Jerusalém. Um relato sobre a banalidade do mal. Tradução José Rubens Siqueira. São Paulo: Companhia das Letras, 1999.

${ }^{4}$ Para uma análise dos aspectos subjetivos e afetivos envolvidos no autoritarismo prussiano, correia de transmissão para o Nazismo na sociedade alemã, ver CERQUEIRA FILHO, Gisálio. Autoritarismo Afetivo: a Prússia como sentimento. São Paulo: Escuta, 2005.

${ }^{5}$ Cf: ARENDT, Hannah. Origens do totalitarismo. Antisemitismo, imperialismo e totalitarismo. Tradução Roberto Raposo. 10ª reimpressão. São Paulo: Companhia das Letras, 2012, p.31-48.
} 


\section{UDIREITO}

O TRIBUNAL DE NUREMBERG E A TEORIA PURA DO DIREITO

alemão contemporâneo seu, Carl Schmitt (1888-1985) 6 . O texto analisará ainda (II) os processos de Nuremberg e a ideia de "injustiça legislativa”7 de Gustav Radbruch (1878-1949). Por fim, (III) propõe-se debater a controvertida "Fórmula de Radbruch" a partir das críticas do próprio Kelsen a respeito da persecução penal dos acusados alemães por ocasião dos julgamentos de Nuremberg.

Diante desse panorama, deseja-se verificar em que medida os pressupostos usados para a persecução penal em Nuremberg se encaixam ou não com as teorias de Kelsen e de Radbruch, e em que medida se justifica ou não as críticas feita à TPD. Busca-se então identificar se há uma relação entre a TPD e formulações jurídicas e ideológicas durante o Terceiro Reich. Visa-se esclarecer se há razões para a acusação ao positivismo, que tem Kelsen como sua principal referência, ${ }^{8}$ e se houve mesmo conivência da TPD com os crimes cometidos pelos nazistas. ${ }^{9} 0$ artigo adota um viés interdisciplinar, ao apontar tanto para aspectos históricos envolvendo o debate entre Hans Kelsen e Carl Schmitt sobre o guardião da constituição, como aspectos teóricos do direito e relativos à jurisprudência.

\section{A TPD E O CONTEXTO HISTÓRICO DE ASCENSÃO DO NAZISMO}

Nesta primeira parte, pretende-se analisar o contexto histórico em que foi formulada a TPD para, em seguida, explicitar as diferentes abordagens sobre os processos realizados no âmbito do Tribunal de Nuremberg. Hans Kelsen partiu da concepção fundamental do que se entende por Direito, passando pelas teorias do Direito Natural para chegar à TDP. ${ }^{10}$ Ela está comummente associada ao direito positivo, pois trata do direito posto/escrito, e não de uma ordem jurídica

\footnotetext{
${ }^{6}$ A este respeito ver KELSEN, Hans. Wer soll der Hüter der Verfassung sein?. In: KLECATSKY, Hans; MARCIC, René; SCHAMBECK, Herbert (org.). Die Wiener Rechtstheoretische Schule. Wien: Europa Verlag, 1968, p. 1873-1922 e SCHMITT, Carl. Der Hüter der Verfassung. Berlin: Duncker \& Humblot, 2016.

${ }^{7} \mathrm{Em} 1946$ Radbruch publicou um artigo, onde escreveu que no conflito entre justiça e segurança jurídica pode ser solucionado naquilo em que o direito positivo, tem precedência, mesmo quando o seu conteúdo é injusto e impróprio, a menos que a contradição entre direito positivo e justiça atinja um nível intolerável em que a lei, como um direito incorreto (unrichtiges Recht), deva render-se a justiça. HALDEMANN, Frank. Gustav Radbruch v. Hans Kelsen: um debate sobre o Direito Nazista. In: FARO, Julio Pinheiro e BUSSINGER, Elda Coelho (org. ). A diversidade do pensamento de Hans Kelsen. Rio de Janeiro: Lumen Juris, p. 279280.

${ }^{8}$ GODOY, Arnaldo Sampaio de Moraes. 0 nacional-socialismo e a equivocada imputação de culpa alemã no contexto das críticas ao positivismo: notas em defesa de Hans Kelsen. In: BORGES, Ivan Cláudio Pereira. A Teoria Jurídica de Hans Kelsen. Rio de Janeiro: Lumen Juris, 2017, p.1-17.

${ }^{9}$ Sobre a crítica de Radbruch de que o positivismo jurídico teria "desarmado" os juristas alemães durante o nazismo, ver especialmente LOSANO, Mario G. Sistema e estrutura no direito, volume 2: o Século XX. São Paulo: Martins Fontes, 2010, p. 235-239.

10 Para uma explanação detalhada da TPD, ver LOSANO, 2010.
} 
específica e, desta forma, não se trata de uma intepretação especial, nacional ou internacional das normas ${ }^{11}$.

Neste ponto é fundamental introduzir o fundamento kantiano da teoria do direito de Kelsen, sobretudo a separação entre a esfera do "ser" (sein) e do "dever ser" (sollen). ${ }^{12} 0$ direito pertenceria na visão de Kelsen à ordem do sollen, do dever ser, e não daquilo que é, que existe na prática (sein). Trata-se de uma construção teórica puramente normativa, referida ao mundo das normas - um “como se” (uma ficção, $a l s o b)^{13}$. Kelsen queria dotar o direito de um objeto que the fosse específico - a norma - o que, para ele, era exigência de uma ciência nova - a do direito - que ele queria fundamentar, distante de todo e qualquer "elemento extrajudicial". ${ }^{14}$ Trata-se, portanto, de uma teoria geral do direito em si (da norma pura), ou seja, a tentativa de se criar uma teoria tão somente jurídica da norma/do direito. ${ }^{15}$

0 jurista austríaco, de origem judaica, ${ }^{16}$ tinha uma preocupação fundamental: conferir ao direito o reconhecimento como ciência autônoma, dotada de neutralidade e coerência metodológica. ${ }^{17}$ Assim, por se tratar de uma construção teórica sobre o direito, Kelsen teve a preocupação epistemológica de delimitar claramente o seu objeto, tentado responder às seguintes perguntas fundamentais: (I) o que é o direito e (II) como é o direito? Sob esse prisma, a intenção do autor não era a de indagar como deveria ou poderiam ser determinadas legislações ou códigos normativos específicos. Trata-se de uma teoria puramente jurídica da dimensão das leis, porque se orienta para a investigação daquilo que, na sua visão, seria genuinamente do direito, excluindose tudo aquilo que não pertence ao seu exato objeto (as normas). Temos, assim, o princípio fundamental do seu método:

Como teoria, ela reconhecerá, única e exclusivamente, seu objeto. Tentará responder à pergunta "o que é" e "como é" o direito e não a pergunta de "como seria" ou "deveria ser" elaborado. É ciência do direito e não política do direito.

\footnotetext{
11 KELSEN, 2013, p. 67-69.

12 LOSANO, op. cit., p. 53.

13 Ibidem, 86.

14 Ibid., 96.

${ }^{15}$ Devemos essa formulação ao Prof. Titular de Ciência Política Gisálio Cerqueira Filho, em troca de e-mails de 4 de julho de 2014.

${ }^{16}$ Para uma biografia de Hans Kelsen, ver MÉTALL, Rudolf Aladár. Hans Kelsen. Leben und Werk. Wien: Franz Deuticke, 1968. Para uma versão em português dos depoimentos autobiográficos de Hans Kelsen, ver KELSEN, Hans. Autobiografia de Hans Kelsen. Rio de Janeiro: Universitária, 2011. Para a biografia mais recente, que saiu por ocasião do centenário da Constituição Austríaca de 1920, ver OLECHOWSKI, Thomas. Hans Kelsen. Biographie eines Rechtswissenschaftlers. Tübingen: Mohr Siebeck, 2020.
}

17 LOSANO, op. cit., p. 121-128. 
Intitula-se Teoria "Pura" do Direito porque se orienta apenas para o conhecimento do direito e porque deseja excluir deste conhecimento tudo o que não pertence a esse exato objeto jurídico. ${ }^{18}$

Todas essas indagações a respeito da filosofia do direito tendem a encontrar respostas melhores "dentro do seu contexto histórico-doutrinário", de modo que, para melhor compreender uma teoria, é mister ter conhecimento sobre o processo histórico de formulação desta. ${ }^{19}$ Trata-se da questão de "dialogar com a história", como sugere o estudioso da história intelectual e cultural Carl Schorske, ${ }^{20}$ procedimento que também funciona como uma chave interdisciplinar para melhor entendermos as questões da dogmática jurídica. Além disso, deve-se advertir ainda sobre a complexidade de se investigar satisfatoriamente (e a fundo) a teoria formulada diante dos mais de seiscentos títulos, entre livros e artigos, deixados por Kelsen, cuja obra teórica foi muito profícua. ${ }^{21}$ Este trabalho não pretende, porém, se aprofundar nos detalhes da TPD, apenas recorrendo pontualmente a alguns de seus pressupostos teóricos com o propósito de melhor contextualizá-los e, assim, expor a crítica formulada por Kelsen aos julgamentos do Tribunal de Nuremberg.

Deve ser frisado que, para o jurista austríaco, a ciência jurídica é dirigida tão-somente ao conhecimento da norma ${ }^{22}$, em contraposição às outras ciências, que procuram explicar os fenômenos naturais ou sociológico-políticos: a ciência do direito não se refere a um estado de coisas realmente existente, mas a uma ordem do sollen (“dever ser”). Daí advém, na visão de Kelsen, o elemento a-ideológico ${ }^{23}$ da TPD, uma vez que uma teoria pura das normas não poderia

${ }^{18}$ KELSEN, 2013, p. 67.

19 VASCONCELOS, Arnaldo. Teoria Pura do Direito: repasse crítico de seus principais fundamentos. $2^{\mathrm{a}}$ ed., Rio de Janeiro: editora G Z, 2010, p. 2.

20 SCHORSKE, Carl. Pensando com a história: indagações na passagem para o modernismo. São Paulo: Companhia das Letras, 2000.

${ }^{21}$ VASCONCELOS, op. cit., p. 3.

22 Ibidem., p. 2.

${ }^{23}$ Não concordamos com o corriqueiro o pensamento no sentido de que o pesquisador é um sujeito cujo saber é inteiramente racional e objetivo, imune as perturbações da subjetividade pessoal, assim também como das influências sociais. Diferente disso, se for investigado em suas condições concretas de trabalho, é facilmente constatável que a razão científica não é imutável. Ela muda, é histórica, e "como o próprio Bachelard costumava dizer, em seus cursos em Sorbonne, que a epistemologia consistia, no fundo, na história da ciência" (JAPIASSÚ, Hilton. Introdução ao pensamento epistemológico. $2^{a}$ ed. Rio de Janeiro: F. Alves, 1977, p.63). Significa dizer que, em matéria de ciência, não existe objetividade absoluta, assim também como o cientista não pode se dizer neutro, a não ser por ingenuidade, ou por uma crença no mito da neutralidade científica. Surge a necessidade de refletir sobre a ciência enquanto fenômeno social ou produto da sociedade, uma vez que, por maior que seja o papel da ciência no desenvolvimento da sociedade, é esta que controla as suas funções. Ainda que rigorosamente elaborada em alto nível técnico, nem por isso a informação científica deixa de apresentar-se como um discurso, que não pode prescindir de uma intenção, nem que seja inconsciente. Cf. JAPIASSÚ, Hilton. 0 mito da neutralidade científica. Rio de Janeiro: Imago Editora, 1975. Kelsen afirma cabalmente, sobre este ponto: “Essas tendências ideológicas (...) ainda 
se curvar a inclinações ideológicas particulares de qualquer natureza, como no caso da Teoria Natural Clássica. ${ }^{24}$

Uma das preocupações de Kelsen era fazer a norma ser compreendida como ato e substrato de sentido. Nesse sentido, é fundamental a diferenciação entre ciência do direito, que faz uso de uma linguagem descritiva, e direito, que faz uso de uma linguagem prescritiva. ${ }^{25} \mathrm{Tal}$ diferença remonta à distinção, introduzida por Kelsen posteriormente em sua obra, entre "norma jurídica” (Rechtsnorm) e “proposição jurídica” (Rechtssatz):

A proposição jurídica, em particular, não é um imperativo: é um juízo, ou seja, uma assertiva concernente a um objeto que se propõe conhecer [...]. 0 jurista que descreve cientificamente o direito não se identifica com a autoridade jurídica que estatui a norma. A proposição jurídica permanece uma descrição objetiva, mas não se torna prescrição. ${ }^{26}$

O direito é uma ordem normativa da conduta humana e, dessa forma, tem a função de regular como o comportamento humano deveria ser. Se um juiz julga um caso concreto no qual se apura a existência de um delito, dirige seu conhecimento, em primeiro lugar, a um ser natural, para posteriormente, ter lugar uma decisão próxima apenas de um fato natural. Sua sentença será, assim que se comprovar a subsunção do fato à norma, interpretada como um reconhecimento jurídico sobre a existência de um delito. Mas o magistrado só poderá interpretá-lo assim, desde que este fato seja identificado e adequado ao conteúdo da norma, mantendo-se a premissa de legalidade. Parte-se, portanto, da norma geral (lei em abstrato) para se chegar à norma individualizada (a sentença), desde que haja uma norma anterior. Neste sentido, afirma Kelsen que

Se o juiz comprova um caso concreto - possivelmente um delito - dirige seu conhecimento, em primeiro lugar, a um ser natural - tem lugar uma sentença, próxima apenas de um fato natural.

Mas juridicamente, sua sentença será, assim que se comprovar o fato e a lei (a ele) correspondente, interpretada logo como "furto" ou "fraude". E só assim poderá interpretá-lo, desde que o conteúdo desse fato seja reconhecido, de maneira totalmente específica, como o conteúdo de uma norma. ${ }^{27}$

prevalecem na dominação da atual ciência do direito (...) É contra ela que se insurge a Teoria pura do Direito" (KELSEN, 2013, p. 81-82.)

${ }^{24}$ Ibidem., 71-73.

${ }^{25}$ LOSANO, 2010, p. 82.

${ }^{26}$ KELSEN, La dottrina pura del diritto, apud. LOSANO, op. cit., p. 63.

${ }^{27}$ KELSEN, 2013, p. 71-73. 


\section{UDIREITO}

O TRIBUNAL DE NUREMBERG E A TEORIA PURA DO DIREITO

Percebe-se, portanto, uma preocupação de Kelsen com a legalidade e a anterioridade da lei na TPD.

No contexto histórico da formulação kelseniana emergia como força política na Europa dos anos 1930 o nacional-socialismo. A ascensão do Partido Nacional-Socialista fundamentou-se juridicamente nos princípios de Gleichschaltung (comprometimento) e de Führerprinzip (obediência ao líder político). ${ }^{28}$ Foi nesse cenário jurídico-político que se fortaleceu o poder pessoal de Hitler, de cunho carismático, utilizando-se habilmente das novas mídias, em especial o rádio, para conquistar a opinião pública. A premissa do poder exercido pelo Führer era uma visão do direito como poder pessoal, resultante do conceito teológico-político de "soberania" daquele que detém o poder, tal como formulado por Carl Schmitt, ${ }^{29}$ somando-se ainda um aparato político-jurídico calcado na ideia de inimigo. ${ }^{30}$

Derrotada na Primeira Guerra Mundial, a Alemanha perdeu territórios e viu-se obrigada a aceitar condições degradantes no Tratado de Versailles. ${ }^{31}$ Hitler alcançou o poder político legitimamente, ou seja, por dentro da Constituição de Weimar (1919), ${ }^{32}$ pois que esta previa leis de exceção que o permitiram governar de forma autocrática, adotando o discurso clássico dos líderes autoritários (ontem e hoje): o fim da corrupção, a eliminação "ameaça vermelha", associada a uma conspiração judaica internacional, num momento em que a maioria da população alemã estava desempregada e em situação de penúria existencial (agravada pela hiperinflação). Assim, Hitler habilmente se aproveitou do terreno fértil deixado pela Primeira Guerra Mundial para propagar suas ideias a respeito do que consistiria, no seu entender, numa nova Alemanha.

O desemprego era alto e Hitler afirmava haver previsto a catástrofe, dizendo-se diretamente interessado nas oportunidades de renovação que a depressão trazia. ${ }^{33}$ Nesse contexto, a liderança nazista em torno de Hitler utilizou-se de argumentos antissemitas e dos meios de comunicação de massa para disseminar a ideia da responsabilidade do povo judeu por muitas das dificuldades que o país enfrentava (acusava-os da ameaça comunista, da desagregação social, do controle das finanças mundiais e da mídia). ${ }^{34} \mathrm{Em}$ meio a comícios monumentais,

\footnotetext{
${ }^{28}$ GODOY, 2017, p. 1-3.

${ }^{29}$ A esse respeito ver SCHMITT, Carl. Der Begriff des Politischen. Berlin: Duncker \& Humblot, 2015.

30 Sobre esse aspecto, ver MEIER, Heinrich. Carl Schmitt, Leo Strauss y El concepto de lo político. Sobre un diálogo entre ausentes. Buenos Aires: Katz, 2008.

31 CHAUÍ, Marilena. Convite a filosofia. 13.ed. $7^{\text {a }}$ impressão. São Paulo: Editora Ática, 2008, p.393-397.

32 Ver AGAMBEN, Giorgio. Estado de Exceção. São Paulo: Boitempo, 2004.

33 SHIRER, William L. Ascensão e Queda do Terceiro Reich, volume I. Rio de Janeiro: Editora Civilização Brasileira S.A., 1962, p. 210.

34 HAFFNER, Sebastian. Geschichte eines Deutschen. Als Engländer maskiert. München: Deutsche VerlagsAnstalt, 2006.
} 
potencializados pela força dos megafones, que lhe permitiu atingir massas de pessoas, somado ao novo poder da transmissão radiofônica para todo o país, o poder retórico de Hitler amplificou-se. Tratava-se de um discurso que mobilizava a noção de "Pátria" (Vaterland), argumentando que a Alemanha não poderia mais suportar um conglomerado de raças, uma mistura de povos, que corroía a "legítima" cultura alemã, constituindo-se como um perigo maior do que todos os canhões dos inimigos que haviam atingido o país durante a Primeira Guerra Mundial. ${ }^{35}$ A derrota alemã, porém, não teria se dado, segundo o discurso mobilizado por Hitler, no campo de batalha, mas sim devido aos "patifes" ${ }^{36}$ que se recusaram a lutar, desejando assim que a guerra terminasse logo. Assim, o Partido Nacional Socialista foi eleito nas eleições de 1932 para o parlamento com pouco mais de 33\% dos votos e, a seguir, a concentração de poder nas mãos de Hitler não pode mais ser parada a partir de 1933: implementou-se aquilo que ficou conhecido como "totalitarismo" nazista. ${ }^{37}$

Destacam-se nos regimes autoritários a supressão sistemática das liberdades civis e individuais, que podem ser exemplificadas pelo fechamento político traduzido no unipartidarismo. ${ }^{38} \mathrm{Em}$ regimes autoritários, a nação é vista como constituída pelo povo como uma massa uniforme representada por uma única agremiação política, em lugar das nuances políticas típicas de um sistema pluripartidário, representativo de um arcabouço jurídico de proteção aos direitos fundamentais, que contrasta com a ideia de um regime de partido único. ${ }^{39}$ Outro aspecto comum ao regime nazista foi a prática da censura, suprimindo-se as liberdades de expressão, sobretudo com o fechamento de veículos editoriais da oposição e com editores/jornalistas de origem judaica. Práticas de delação, na qual o Estado, através de seu partido e, normalmente, por meio da sua polícia secreta, exerce o controle sobre o pensamento e sobre o desenvolvimento das ciências e das artes, se tornaram mais frequentes. 0 mesmo pode ser dito sobre as prisões de opositores, artistas, homossexuais, sindicalistas, estudantes. ${ }^{40}$

Além de todos esses fatores, destacam-se ainda as violações aos direitos fundamentais no regime nazista, presentes na prática da discriminação sistemática a determinados grupos sociais a partir de "leis raciais" (Rassengesetze).${ }^{41} \mathrm{O}$ discurso da superioridade racial ariana, ${ }^{42}$ baseava-

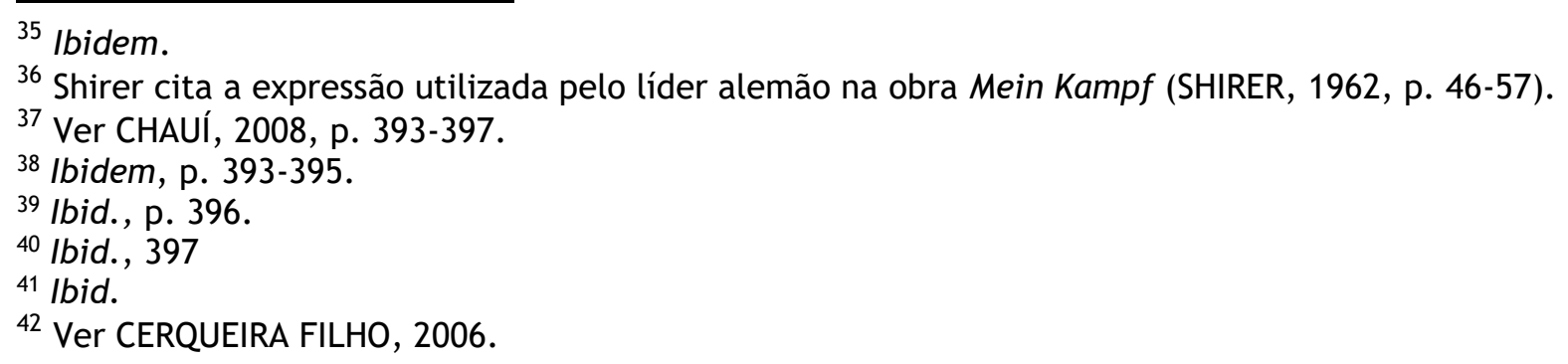


se nas antigas ideias eugênicas e de pureza racial, que não foram inventadas pelos nazistas, mas instrumentalizadas por eles. ${ }^{43}$ Tais leis foram usadas para justificar a retirada dos direitos daqueles pertencentes a raças consideradas “inferiores”. Dessa forma, justificou-se o trabalho forçado, bem como a eliminação física daqueles considerados inaptos, desembocando posteriormente no genocídio cometido nos campos de concentração como parte da assim chamada "solução final" para os judeus. A ideia do extermínio em massa de judeus, ciganos, homossexuais e opositores políticos de um modo geral tornou o genocídio ${ }^{44}$ uma política sistemática do regime nazista. ${ }^{45}$

As ordens de prisão foram um instrumento sumário no regime nazista. As provas estavam na cabeça do julgador-inquisidor, com um forte componente de decisionismo: permitia-se a retroatividade das incriminações e tipificações por analogia ${ }^{46}$, o que por si só já afronta o princípio da legalidade. ${ }^{47} \mathrm{O}$ direito penal, tal como praticado no período nazista, configurou-se como o império do decisionismo jurídico, ou seja, uma práxis jurídica influenciada pelos ditames do poder político e permeável às crenças (políticas) pessoais do julgador. ${ }^{48}$

A destruição do ordenamento jurídico liberal foi atuada abrindo as portas à 'interpretação ilimitada' (unbegrenzte Auslegung): foi abolida a proibição de analogia no direito penal, o Reichsgericht foi libertado do respeito às decisões anteriores, aos juízes foi permitido não aplicar as normas emanadas antes da revolução nacional-socialista se consideradas contrárias ao 'são sentimento

\footnotetext{
${ }^{43}$ Ver LOSANO, 2010, 194-196.

44 Japiassú explica que o genocídio é, na sua essência, um crime contra a humanidade, que, entretanto, dada a sua relevância, foi destacado dessa categoria para que pudesse receber tratamento específico. Em realidade, é um crime internacional de definição recente na história, remontando imediatamente ao período posterior a Segunda Grande Guerra. JAPIASSÚ, Carlos Eduardo Adriano. O Tribunal Penal Internacional. A internacionalização do direito penal. Rio de Janeiro: Lúmen Júris, 2004, p. 201/221. Ressalte-se que o Tribunal de Nuremberg, onde se firmou o entendimento sobre esses delitos, foi o marco histórico inicial na construção da ideia de post conflict justice (justiça de transição). Ver TEITEL, Ruti. Transitional Justice Genealogy. Harvard Human Rights Journal. Vol. 16, 2003. Disponivel em: https://www.qub.ac.uk/Research/GRI/mitchell-institute/FileStore/Filetoupload,697310,en.pdf. Acesso em: 11 nov. 2020.

${ }^{45}$ Destacam-se dois grupos que foram sistematicamente alvo das políticas nazistas: o primeiro formado por aqueles que viviam à margem da sociedade, uma vez que não conseguiam se adequar aos valores impostos pelo trabalho, pelos ideais de higiene e sobriedade, integrando esse primeiro, grupo, por exemplo, alcoólatras, prostitutas, mendigos e doentes mentais. Registre-se que, qualquer que fosse o tratamento dispensado a essas pessoas, eles nunca desapareceram da sociedade alemã por completo, apesar das tentativas de confinamento forçado. Ver GELLATELY, Robert. Os marginais sociais e a consolidação da ditadura de Hitler, 1933-1939. Tradução Beatriz Medina. In: ROLLEMBERG, Denise; QUADRAT, Samantha Viz (Orgs.) Construção Social dos Regimes Autoritários. Legitimidade, consenso e consentimento no século XX - Europa. Rio de Janeiro: Civilização Brasileira, 2010, p.207-242.

${ }^{46}$ GODOY, 2017, p. 2.

${ }^{47}$ BATISTA, Nilo. Introdução Crítica ao Direito Penal. Rio de Janeiro: Revan, 2003, p.65-83.

${ }^{48}$ Essa discussão é feita em LOSANO, 2010, p. 235-242.
} 
popular'; por fim, no direito privado, fez-se um uso muito amplo das cláusulas gerais. ${ }^{49}$

A partir dessa lógica, quando as normas se adequavam aos propósitos do líder político, deviam ser cumpridas. ${ }^{50}$ Por outro lado, quando criavam entraves e inconveniências, as normas positivadas eram ignoradas e descartadas como sendo inválidas. Em razão disso, "não há como sustentar que a ordem nazista era substancialmente positivista"51. Esse argumento servira em grande medida para absolver os juízes da sua conivência com o nacional-socialismo nos processos do pós-Guerra. Porém, ignora-se ainda que a luta contra o positivismo era uma luta contra a República de Weimar e o caráter social-democrata que ele representava. ${ }^{52} \mathrm{~A}$ conjuntura foi propícia para a realização de uma série de comícios inflamados de Hitler por todo o país, propiciando terreno fértil para aquilo que atualmente se chama de “discurso de ódio", direcionado a determinados grupos sociais - os famosos hate speech, usados e abusados pelo partido nazista como arma de propaganda na luta ideológica. ${ }^{53}$

Os juízes alemães eram um produto da educação jurídica que recebiam, mergulhados no jusnaturalismo conservador ${ }^{54}$, de modo que a parcialidade com que aplicaram a lei no período nacional-socialista é flagrante:

\begin{abstract}
"Os juízes do Estado oitocentista eram recrutados com critérios homogêneos aos do Estado: eram pessoas autoritárias e conservadoras. [...] quanto mais um Estado era autoritário, mais os juízes estavam dispostos a ater-se rigorosamente ao seu direito. [...] Na verdade, os juízes alemães não agiram como positivistas nem durante a República de Weimar, nem durante o regime nacional-socialista" 55
\end{abstract}

Os juízes alemães nunca haviam aceitado, portanto, nem a República de Weimar, nem aquilo que consideram a sua ideologia social-democrata e não havia ninguém que representava mais aquela ideologia do jurista austríaco Hans Kelsen. Apesar de nunca ter pertencido à qualquer

\footnotetext{
${ }^{49}$ Ibidem, 2010, p. 231.

50 Ibid., p. 205.

51 GODOY, op. cit., p. 8. 2019-3.

53 SHIRER, 1962, p. 101.

${ }^{54}$ LOSANO, 2010, 240.

55 Ibidem, p. 238.
}

52 Ver LOSANO, op. cit., 240. A respeito da recepção de Kelsen e da Constituição de Weimar no Brasil, ver BORRMANN, Ricardo G. A recepção de Hans Kelsen na Constituinte de 1933-34: Entre Positivismo Jurídico e Neotomismo. In: NEDER, Gizlene; SILVA, Ana Paula Barcelos Ribeiro da Silva; SOUZA, Jessie Jane Vieira de (orgs.). Intolerância e Cidadania: secularização, poder e cultura política. Rio de Janeiro: Autografia, 2015, p. 396-421. Sobre os elementos social-democratas da Constituição de Weimar e sua recepção no Brasil, vejase ainda HOFFMANN, Fábio; LEITE, Fábio Carvalho. Die Wirkung der Weimarer Verfassung: ein Blick nach Brasilien. Kritische Justiz, Vol. 52 (2019), Issue 3, p. 265-279. DOI: https://doi.org/10.5771/0023-4834- 
agremiação política, era considerado o pai da constituição austríaca de 1920, feita sob o chanceler social-democrata Karl Renner (1870-1950) ${ }^{56}$, este considerado também o “pai” da República austríaca. Se Renner era o pai da república, Kelsen sem dúvida é considerado o "pai” de sua carta magna.

A ideologia nacional-socialista, por seu turno, foi sempre contrária ao direito, considerando-o como um empecilho aos desígnios do Führer. Assim, com as exceções de Carl Schmitt e Karl Larenz (1904-1964), o período nazista não teria produzido teorias jurídicas relevantes ${ }^{57}$ : as teses de Schmitt sobre "os ordenamentos concretos" e de Larenz sobre "conceitos gerais e abstratos" se afirmaram, aos olhos dos nacional-socialistas, como as "únicas verdadeiramente adequadas à ideologia nacional-socialista". ${ }^{58}$ Enquanto Larenz queria libertar o juiz do vínculo à letra da lei para condicioná-lo à outro valor político, destruindo o ordenamento jurídico em favor de uma "interpretação ilimitada" (unbegrenzte Auslegung), ${ }^{59}$ o conceito de “ordenamentos concretos" (konkrete Ordnungen) de Schmitt serviu para "fundar uma teoria jurídica que permitisse esvaziar o direito vigente" ${ }^{00}$, permitindo a substituição de dispositivos jurídicos por conceitos políticos. Assim,

A teoria de Schmitt não se propõe descrever um direito vigente, mas oferecer ao nacional-socialismo um instrumento para modificar, completar e cancelar o direito vigente herdado do passado. Mais do que uma teoria do direito, é a teoria para uma política do direito e precisamente para uma política nacional-socialista do direito. ${ }^{61}$

\section{AS CRÍTICAS DE RADBRUCH AO POSITIVISMO KELSENIANO}

O positivismo jurídico de corte kelseniano foi acusado por Radbruch de ter "desarmado" juízes alemães, ${ }^{62}$ já que muitos dos acusados em Nuremberg alegaram o estrito cumprimento de ordens legais:

\footnotetext{
56 BORRMANN, Ricardo Gaulia. Hans Kelsen and the Austrian Constitutional Court: family law, political conciliation and religious culture (1919-1930). Sociologia del diritto n. 3, 2014, p. 65-91. Disponível em: https: / /dialnet.unirioja.es/servlet/articulo?codigo=5086964. Acesso em 03 nov. 2020.

57 LOSANO, op. cit., p. 193.

58 Ibidem, p. 211.

${ }^{59}$ Ibid., p. 231.

60 Ibid., 212.

61 Ibid.

62 Ibid.
} 
[...] exatamente a autoridade moral de Radbruch favoreceu a difusão dessa condenação do positivismo, que não só serviu para reforçar as posições conservadoras em geral, mas involuntariamente jogou também uma bóia de salvamento aos juristas comprometidos com o regime nacional-socialista." 63

A TPD e o positivismo de Kelsen foram criticados por supostamente terem sido coniventes com os crimes cometidos pelo regime nazista, uma vez que a defesa kelseniana da pureza científica do direito seria reducionista, pois a ciência jurídica somente se preocuparia com as normas. ${ }^{64} \mathrm{~A}$ mais difundida crítica ao positivismo é que o seu olhar formalista pode legitimar qualquer vontade política trasvestida sob a forma de leis. ${ }^{65}$ Assim, o direito positivo foi acusado de ter uma característica a-valorativa, e isso teria possibilitado a experiência do estado totalitário na Alemanha. Com o propósito de defender uma suposta superação do positivismo kelseniano, sustenta-se até mesmo que os juízes alemães adotaram-no durante o nazismo como fundamento de seus julgamentos. ${ }^{66}$ No entanto, demonstrou-se como esse posicionamento é frágil e não está apoiado em pesquisas de fonte documental (julgamentos ou jurisprudência). Insiste, portanto, Radbruch na necessidade de abandonar o positivismo jurídico de Kelsen e, por outro lado, partir para uma nova teorização baseada numa "ética de valores”, ou seja, principiológica, com o retorno destes ao direito ${ }^{67}$.

Ao contrário do que se afirma, “os juristas alemães se referiam (...) prevalentemente ao jusnaturalismo católico" em que foram educados nas faculdades jurídicas, e "ao neotomismo conservador que muitas vezes, como para Carl Schmitt, havia sido já a doutrina-guia deles antes da conversão ao nacional-socialismo". ${ }^{68}$

As acusações contra o positivismo não estão amparadas, portanto, nem pela história, nem pela teoria. Assim, o argumento de que a TPD se prestou a fundamentar o direito no regime nazista pode ser descartado, pois não encontra bases na obra teórica de Kelsen. A posição crítica a Kelsen insiste, sem qualquer fundamento empírico, na tentativa de demostrar a necessidade de se abandonar o positivismo jurídico (kelseniano) e, por outro lado, partir para uma nova teorização

\footnotetext{
63 Ibid., p. 235.

64 GODOY, 2017, p. 11.

65 Ibidem.

${ }^{66}$ BARCELLOS, Ana Paula de. Ponderação, racionalidade e atividade jurisdicional. Rio de Janeiro: Renovar, 2005, p. 8.

67 DIMOULIS, Dimitri. Positivismo jurídico e senso comum. In: DIMOULIS, Dimitri (org.). A Relevância Prática da Teoria do Direito. Belo Horizonte: Arraes editores, 2016, p. 9.

68 LOSANO, 2010, p. 240. A respeito das permanências históricas de longa duração do tomismo na cultura jurídica brasileira do XIX e no direito penal brasileiro, veja-se: NEDER, Gizlene. Idéias jurídicas e autoridade na família. Rio de Janeiro: Revan, 2007 e NEDER, Gizlene; CERQUEIRA FILHO, Gisálio. Criminologia e Poder Político. Sobre Direitos, História e Ideologia. Rio de Janeiro: Lumen Juris, 2006.
} 


\section{UDIREITO}

O TRIBUNAL DE NUREMBERG E A TEORIA PURA DO DIREITO

baseada numa ética de valores, ou seja, principiológica. Mas já demonstrou-se que o nazismo não implementou grandes modificações no ordenamento jurídico alemão, pois utilizou-se da (i)legalidade governamental e da (re)interpretação do direito conforme os valores políticos nazistas e os interesses dos julgadores. Além disso, o nazismo visava instituir um "Estado de Justiça", e o positivismo era visto como a negação desse ideal de "justiça" nacional-socialista. ${ }^{69}$ Por fim, as teorias jurídicas invocadas pelo nacional-socialismo tinham claras referências à vontade do Führer, que passou a ter força de lei. ${ }^{70}$ Nas decisões proferidas, os magistrados muitas vezes recorriam a valores nacionalistas, patrióticos e racistas (o que em si já é contrário à teoria de Kelsen, já que o direito não pode jamais se basear em valores ou conceitos políticos para retirar seus fundamentos) - o que contrariava frontalmente a visão positivista. ${ }^{71}$

Tal crítica ao positivismo de Kelsen ainda confunde os requisitos de validade da norma com os requisitos de validade do sistema jurídico. Ignora-se ainda o fato de que Hans Kelsen foi hostilizado e perseguido, primeiro pelo fascismo do regime de Engelbert Dollfuß (1892-1934) na Áustria, e depois pelos nazistas, que tinham repulsa pelo positivismo jurídico. Dollfuß, por exemplo, não apenas dissolveu o Tribunal Constitucional criado por Kelsen, retirando-o da corte, como ainda viu-se obrigado a dissolver, em seguida, a própria Constituição kelseniana de 1920, uma vez que governar autoritariamente com ela era impossível, devido ao seu foco legislativo e seu sistema de freios e contrapesos, tendo o Tribunal Constitucional como fiel da balança. Tais fatores indicam, no mínimo, uma fragilidade das críticas a Kelsen. ${ }^{72}$

A história demonstra que o jurista vienense ${ }^{73}$ foi consultor jurídico na elaboração da Constituição republicana da Áustria, que em 2020 completa 100 anos de promulgação. Assim, o nome de Kelsen vem sendo (re)lembrado como "arquiteto" jurídico da carta (e da democracia) austríaca por ocasião das celebrações de seu centenário. ${ }^{74}$ Kelsen foi o responsável pela elaboração do projeto de base da Constituição, lecionando ainda na Universidade de Viena entre 1919 e $1930 .{ }^{75}$ Além disso, o jurista foi também magistrado na Corte Constitucional (por ele mesmo

${ }^{69}$ DIMOULIS, op. cit., p. 9.

70 LOSANO, 2010,p. 202. Ver ainda AGAMBEN, 2004.

${ }^{71}$ DIMOULIS, op. cit., p. 9.

72 Ibidem, p. 10.

${ }^{73}$ Apesar de não ser originário de Viena, mas de Praga, Kelsen pode ser considerado um jurista vienense. Ver JABLONER, Clemens. Kelsen and his circle: The Viennese years. European Journal of International Law 9 (1998), 368-385.

74 Ver https://kurier.at/kultur/hans-kelsen-ausstellung-der-designer-der-demokratie/401049589. Por ocasião do centenário o Museu Judaico vienense oferece uma exposição sobre o jurista, onde a sua obra constitucional é descrita como uma "constituição elegante": http://www.jmw.at/en/exhibitions/hanskelsen-and-elegance-austrian-constitution. Acesso em: 03 nov. 2020.

${ }^{75}$ KELSEN, 2011, p. 71. 


\section{UDIREITO}

O TRIBUNAL DE NUREMBERG E A TEORIA PURA DO DIREITO

criada), a partir de 1919 e até sua dissolução pelo governo fascista de Dollfuß em 1929, tendo como desculpa o propósito de "despolitiza-la". ${ }^{76} 0$ Tribunal Constitucional austríaco era o único de sua espécie até aquele momento, tendo sido posteriormente copiado por vários países, inclusive pela Alemanha no Pós-Guerra.

Em 1934, Kelsen publicaria a sua obra Teoria Pura do Direito, mas viu-se obrigado a fugir da Alemanha em 1933, onde lecionava desde $1930^{77}$, primeiro para a Suíça, onde lecionou por alguns anos em Genebra e, posteriormente (1940), para os Estados Unidos da América. Ali passou por Harvard por um curto período de tempo e a partir de 1942 estabeleceu-se definitivamente em Berkeley, primeiro como Lecturer (conferencista), depois como Professor Titular do Departamento de Ciências Política (a partir de 1945), onde lecionou até $1952^{78}$. Ele viria a falecer em 1973, aos 92 anos de idade, na Califórnia ${ }^{79}$.

Kelsen era um entusiasta da cientificidade e da neutralidade ontológica no direito, isso é inegável. ${ }^{80}$ Porém, afirmar que o positivismo jurídico kelseniano compactuou com o regime nazista ou lhe serviu de suporte, é ignorar tanto a sua história como intelectual, perseguido pelos fascistas em Áustria e Alemanha, como os pressupostos de sua TPD. Estes são diametralmente contrários ao "decisionismo" 81 praticado pelos nazistas, como bem exemplificado pelo filme de 1975 do diretor Costa Gavras, Sessão Especial de Justiça.

\section{O TRIBUNAL DE NUREMBERG E AS VIOLAÇÕES DE DIREITOS HUMANOS}

A fim de melhor compreender o contexto histórico dos processos levados a cabo pelo Tribunal de Nuremberg, é necessário fazer uma breve digressão a respeito do interregno que vai do fim da Primeira Guerra Mundial até o início da Segunda. O propósito aqui é delinear o que seria considerado como um conflito “injusto”. Tratar-se-á, então, do conceito de "agressão"82 e da busca por parâmetros punitivos no cenário do direito penal internacional que pudessem fundamentar a persecução penal dos criminosos de guerra nazistas.

\footnotetext{
${ }^{76}$ A respeito da atuação de Kelsen como juiz da Corte Constitucional austríaca, ver BORRMANN, 2014.

77 Ver MÉTALL, 1968, p. 61.

78 KELSEN, 2011, p. 107-109/120.

79 GODOY, 2017, p. 11.

${ }^{80}$ Ver a este respeito, por exemplo, o prefácio à primeira edição da TPD, escrito em Genebra e datado de 1934: KELSEN, Hans. Prefácio à primeira edição. In: Idem. Teoria Pura do Direito. São Paulo: Martins Fontes, 2009, p. XI-XV.

81 Sobre as críticas ao decisionismo no Brasil ver STRECK, Lênio Luiz. Verdade e consenso: constituição, hermenêutica e teorias discursivas. São Paulo: Saraiva, 2012.

82 JAPIASSÚ, 2004, p.252.
} 
A análise do conceito de "agressão" surgiu efetivamente a partir da ideia de limitar conflitos armados, algo que teve início no período entreguerras: "assim, tanto o Tratado da Sociedade das Nações, de 1919, quanto o Kellogg-Briand (Pacto de Paris), de 1928, continham normas que condenavam o recurso da guerra para a solução das controvérsias". ${ }^{83}$ Com efeito, naquele momento não foi possível definir com precisão o crime de agressão, mas em linhas gerais este pode ser considerado como "o ato de iniciar um conflito armado de forma injustificada"(delitos contra a paz). ${ }^{84}$

Além da questão da agressão, discutia-se no pós-Guerra como punir a Alemanha pelas hostilidades praticadas durante a Primeira Guerra Mundial, e qual seria a forma de responsabilização adequada, se ela se daria no plano nacional ou internacional. Em termos de justiça, não se ignorava que os vencedores não poderiam repetir os erros cometidos no Tratado de Versalhes, cujas pesadas reparações foram impostas pelos Aliados sem qualquer diálogo ou participação dos vencidos.

Os julgamentos do Tribunal de Nuremberg buscaram não reincidir nos mesmos erros. Com o final da Segunda Guerra e o armistício da Alemanha em 8 de agosto de 1945, ocorreu a Conferência de Londres, onde as quatro potências vencedoras celebraram um acordo destinado a estabelecer as regras para orientar os processos dos criminosos de guerra. 0 resultado desse acordo ficou conhecido como Nuremberg Charter (Carta de Nuremberg), que propiciou a formação subsequente do Tribunal $^{85}$, constituindo-se como primeiro grande marco em termos da responsabilização jurídica por violações de direitos humanos. ${ }^{86}$ Após os julgamentos, as penas capitais de enforcamento foram executadas no dia 16 de outubro de 1946, na própria prisão anexa ao tribunal de Nuremberg. Os condenados a penas privativas de liberdade foram transferidos para a prisão de Spandau, nos arredores de Berlim, reservada com exclusividade para criminosos de guerra, que ficou sob administração das potências vencedoras. ${ }^{87}$

\footnotetext{
83 Ibidem, p.252.

84 Atualmente este é considerado como a parte das infrações penais internacionais de mais imprecisa conceituação. O crime de agressão somente foi definido quando da aprovação da Resolução 3314 (XXIX), da Assembleia Geral das Nações Unidas. Apesar disso, os documentos internacionais subsequentes não necessariamente a utilizaram, o que demonstrou que tal conceituação não foi convincente. Ver ibidem, p.253.

85 JAPIASSÚ, 2004, p. 48.

${ }^{86}$ Ressalte-se ainda que, dentre os motivos que pesaram na escolha da cidade alemã de Nuremberg, entre outras considerações de cunho mais prático, estão também fatores simbólicos, já que ali ocorreram os espetaculosos comícios do partido nazista e foram promulgadas as leis de perseguição racial. Ibidem, p. 50. 87 Ibid., p. 50-52.
} 


\section{A “FÓRMULA DE RADBRUCH” E AS CRÍTICAS DE KELSEN AOS PROCESSOS DE NUREMBERG}

O jurista Gustav Radbruch formulou uma teoria que pudesse enquadrar os atos cometidos pelas altas autoridades do Terceiro Reich como violações de direito humanos. Vale acrescentar que Radbruch foi pessoalmente perseguido pelo regime nazista, vendo-se obrigado ao exílio interno por ser classificado como “politicamente inconfiável” 88 pelos nazistas e, assim como Kelsen, foi afastado compulsoriamente de suas funções como professor de direito da Universidade de Heidelberg em 1933 (função retomada em 1945). A sua teoria pode ser interpretada como uma tentativa de criar subsídios para a reconstrução de uma nova ordem de valores a partir das lições extraídas do passado alemão ${ }^{89}$.

Já em 1945, Radbruch formulou a crítica de que o positivismo, com a sua ideia de que "o direito positivado é direito" ${ }^{\circ 0}$, teria feito com que os juristas alemães ficassem a mercê da aplicação de leis arbitrárias e criminosas impostas pela cúpula do partido nazista. Impactado pelas consequências políticas e pela tragédia humana provocadas pelo Terceiro Reich, Radbruch passou a acusar os partidários do positivismo jurídico de terem deixado os juízes impotentes e submissos às ilegalidades nazistas, o que teria facilitado a imposição legal das perseguições políticas e dos julgamentos de exceção ocorridos durante o regime, que pôde então contar com a legitimação da estrutura jurídica. ${ }^{91}$

Em 1946, Radbruch escreveu que o conflito entre a justiça e a segurança jurídica pode ser solucionado quando a contradição entre o direito e a justiça é tão forte e "insuportável”, que a lei positiva "incorreta" deve se render à justiça e ser considerada como inválida. ${ }^{92}$ Ele defendeu ainda que a justiça é uma das finalidades do direito positivo e enunciou dois critérios negativos de validade, ou seja, duas restrições com relação ao positivismo, devendo a norma ser apenas considera válida se tiver um caráter justo. Assim, em primeiro lugar, a norma criada em conformidade com o seu procedimento formal perderia a sua validade quando a contradição entre o seu conteúdo e as exigências de justiça tornam-se insuportáveis. Trata-se da "fórmula da insuportabilidade" (Unerträglichkeitsformel), conforme a terminologia empregada por

\footnotetext{
88 HALDEMANN, 2005, p. 277.

89 Ibidem, p. 277-279.

90 Ibid., p. 279.

${ }^{91}$ Ibid., p. 277-279.

92 Ibid., p. 280.
} 
Radbruch. ${ }^{93}$ Em segundo lugar, a norma também será considerada inválida quando o legislador não possui a intenção de criar normas justas, sendo essa a “fórmula da injustiça” (Unrechtsformel). Dessa maneira, Radbruch apostou na conciliação entre as finalidades da justiça e da segurança, afirmando que a injustiça causada pelo legislador (“injustiça legislativa”) deverá ser intencional para fins de invalidação da norma ou, não sendo intencional, deve apresentar um caráter “insuportável”94.

O problema jurídico posto pela "Fórmula de Radbruch" é que a alternativa que restou àqueles favoráveis à punição a qualquer custo dos nazistas foi, no fundo, adotar uma posição “jusmoralista”. ${ }^{95}$ Segundo esta posição não seria possível criar o direito sem levar em consideração a moral e a ideia de justiça. Assim, sustentou-se que, caso a contradição entre a lei positiva e a justiça atinja um grau considerado como “intolerável”, a lei deveria ser colocada de lado diante da noção de justiça (“moralismo da validade”). ${ }^{96}$ O problema aqui reside em estabelecer uma linha divisória nítida entre leis que não se constituem como direito e um direito que seja válido, apesar de ter conteúdo injusto ${ }^{97}$.

O fato de Kelsen ter sido vítima da perseguição nazifascista não o impediu de fazer uma análise jurídica criteriosa dos processos do Tribunal de Nuremberg. Apesar dos avanços abertos pelas discussões em torno da tese de Radbruch para o tema da responsabilização jurídica de atos cometidos durante o Terceiro Reich e para a ideia de crimes contra a humanidade, Kelsen fez duras críticas à forma como foram conduzidos os julgamentos de Nuremberg do seu ponto de vista jurídico. Este fato pode ter contribuído ainda para a incompreensão de sua obra e de sua perspectiva positivista no direito.

No verão de 1947, Hans Kelsen publicou um artigo intitulado “O julgamento de Nuremberg será considerado como um precedente do direito internacional?" (Will the judgement in Nuremberg Trial constitute a precedent international Law?). ${ }^{98} \mathrm{Em}$ seu artigo, o jurista adverte que um precedente judicial é uma decisão que serve de modelo para decisões subsequentes em

\footnotetext{
${ }^{93}$ DIMOULIS, Dimitri. Justiça de transição e função anistiante no Brasil. Hipostasiações indevidas e caminhos de responsabilização. In: DIMITRI, Demoulis; MARTINS, Antonio; SWENSSON JUNIOR, Lauro Joppert (Orgs.). Justiça de Transição no Brasil. São Paulo: Saraiva, 2010, p. 114.

94 Ibidem, p. 114.

95 HALDEMANN, 2005, p. 279.

${ }^{96}$ SWENSSON JUNIOR, Lauro Joppert. Punição para os crimes da ditadura militar. Contornos do debate. In: DIMITRI, Demoulis; MARTINS, Antonio; SWENSSON JUNIOR, Lauro Joppert (Orgs.) Justiça de Transição no Brasil. São Paulo: Saraiva, 2010, p. 48.

${ }_{97}^{9}$ HALDEMANN, op. cit., p. 278.

${ }^{98}$ KELSEN, Hans. Will the judgement in Nuremberg Trial constitute a precedent international Law? The International Law Quarterly. Vol.1, n² 2, Cambridge University press, Summer 1947.
} 
casos semelhantes. Para ser precedente, a decisão de um tribunal deve estar em conformidade com certas condições que o Tribunal de Nuremberg não teria observado. A primeira delas é que a decisão judicial estabeleça um novo paradigma jurídico, sendo que este deve resultar da própria decisão do tribunal, e não de ato legislativo, ou de costume, ou de um tratado internacional (que é equivalente à norma). ${ }^{99}$ Kelsen advertiu também para a possibilidade de elaboração de um precedente vinculativo que poderia, futuramente, ser seguido por outras decisões e ser reconhecido como exemplo válido a ser observado em decisões subsequentes. ${ }^{100}$

As críticas elaboradas por Kelsen referem-se sobretudo aos seguintes pontos: o fato de tratar-se de típico tribunal ad hoc, estabelecido pelos vencedores da guerra, que se contrapunha aos princípios da legalidade ${ }^{101}$ e do juiz natural, por conta do julgamento de fatos pretéritos ao seu estabelecimento. Por outro lado, Kelsen também aponta os méritos dos processos, como a forte perspectiva internacionalista por trás da instauração do tribunal, a inédita cooperação entre os estados envolvidos, bem como a criminalização de condutas violadoras do direito humanitário, que constituiu a base do direito internacional e a primeira noção de accountability moderna. ${ }^{102} \mathrm{~A}$ preocupação de Kelsen era dotar o tribunal, portanto, de um fundamento jurídico mais rigoroso e não casuístico, ou seja, que não fosse vinculado a um caso particular, e que pudesse, por sua vez, ser aceito como fundamento para um sistema de direito internacional. Às questões de direito internacional Kelsen dedicaria a maior parte de sua trajetória intelectual “madura”, ou seja, após a sua mudança para os EUA. ${ }^{103}$

\footnotetext{
99 "A precedent is a judicial decision which serves as a model for subsequent decisions of similar cases. in order to be a precedent, the decision of a tribunal must conform with certain formal and material conditions which the judgment of Nuremberg does not fulfil. The first condition is that the judicial decision must establish a new rule of law. This rule of law must be created by the judicial decision, not by the act of a legislative organ, or by custom, or by an international treaty (which is equivalent to legislation)". KELSEN, 1947, p. 153.

100 "If there is no legal rule conferring upon a judicial decision the character of a legally binding precedent, this decision has a certain chance of being followed by other decisions on condition that it is recognized as a worthy example for the decision of subsequent similar cases." Ibidem, p. 164.

101 "The rule against retroactive legislation has certainly not been respected by the London Agreement. However, this rule is not valid at all within international law, and is valid within national law only with important exceptions." Ibid., p. 164.

1020 termo accountability, neste sentido, se refere à prestação de contas pela revelação da realidade cruel da Segunda Guerra, em particular, do extermínio dos judeus pelos nazistas e pela brutalidade da agressão japonesa na China, o que provocou a criação de dois tribunais internacionais, o de Nuremberg e o de Tóquio, e com eles a definição, pela primeira vez, dos crimes internacionais próprios. Ver JAPIASSÚ, 2004, p. 43. Também surge a partir desse marco o conceito de justiça de transição que pode ser definida como o processo de julgamentos, expurgos, e reparações que tomam lugar após transições de regimes políticos. Ver CRUZ, Eugeniusz. Justiça de transição no Brasil: análise crítica da persecução penal dos agentes da ditadura. Curitiba: Juruá, 2015.

${ }^{103}$ Ver LOSANO, Mario G. Presenças italianas em Kelsen. In: KELSEN, Hans. Direito internacional e Estado soberano. São Paulo: Martins Fontes, 2002, p. 1-76.
} 
A crítica mais incisiva em relação aos julgamentos referiu-se a violação da irretroatividade, outro ponto levantado por Kelsen, e também aceito por outros juristas posteriormente. ${ }^{104}$ Diante dessa crítica, porém, argumentou-se ainda pela possibilidade de negar que houve efetivamente a afronta ao princípio da retroatividade, ao se sustentar que os réus foram processados por crimes já previstos no direito internacional na ocasião em que estes foram cometidos. ${ }^{105}$ Esse passo, no entanto, dependeu de muita criatividade no exercício da advocacia e de estratégias acadêmicas. ${ }^{106}$ Essa foi a argumentação aplicada pelos juízes para proceder nas condenações e negar que os veredictos punitivos violaram um dos mais elementares princípios penais (princípio da legalidade formal). ${ }^{107}$

A partir dessa experiência houve um giro de paradigmas, tanto na questão de responsabilização penal nacional, que passou para o âmbito internacional, quanto da ótica da responsabilização coletiva (de Estado), que passou para a esfera individual. ${ }^{108} \mathrm{~A}$ corriqueira alegação da defesa em caso de crimes de guerra, feita com base no argumento da obediência a ordens hierarquicamente superiores, não inviabilizou, sob a ótica dos princípios de Nuremberg, a condenação, "por terem perpetrado atos que nenhum ser humano, sob nenhuma circunstância, teria o direito de realizar". ${ }^{109}$ Após mais de meio século dessa experiência, então inédita no âmbito do direito, é possível afirmar que:

104 OHLIN, Jens David. On the Very Idea of Transitional Justice. The Whitehead Journal of Diplomacy and International Relations, Vol. 8, No. 1, p. 51-68, 2007. Disponível em: <http://papers.ssrn.com/sol3/DisplayAbstractSearch.cfm. Social Science Research Network (SSRN). Acesso em 20 de novembro de 2019. "The most trenchant criticism of the Nuremberg trials appealed to the principle of legality, or 'nullum crimen sine lege' (...) in the aftermath of World War II, there were only two logical possibilities. The first is to deny that prosecutions violated the principle of 'nullum crimen sine lege', and argue that defendants were charged with crimes that were already well established in international law. This took a fair amount of creative lawyering and strategic scholarship. Certainly this was the strategy of the judges at International Military Tribunal, for they could never admit that their guilt verdicts violated one of the most fundamental principles of criminal law." Ver ainda a este respeito JAPIASSÚ, 2004,p. 57. 105 OHLIN, 2007, p. 51-68.

106 Ibidem.

107 ZAFFARONI, Eugenio Raul; BATISTA, Nilo; ALAGIA, Alejandro; SLOKAR, Alejandro. Direito Penal Brasileiro- vol.I. 4. Ed. Rio de Janeiro: Revan, 2011, p. 201.

108 "In Nuremberg Principles, for the first time, responsibility for atrocities under international law is attributed to the individual. Under traditional military rules, 'due obedience' to orders was a defense, but under Nuremberg Principles, even those acting under orders of their superiors could be held responsible". Ver TEITEL, Ruti. Transitional jurisprudence: the role of law in political transformation. Yale Law Journal. Vol. 106, No. 7 (May, 1997), p. 2039. Disponível em: https://www.jstor.org/stable/797160. Acesso em: 11 nov. 2020.

109 RIBEIRO, Fernando José Armando. Entre a continuidade e ruptura: Revolução e formalismo no direito moderno. Revista do Instituto de Hermenêutica Jurídica. Vol.8, n.8, (2010). Belo Horizonte, p. 81/98. 


\section{UDIREITO}

O TRIBUNAL DE NUREMBERG E A TEORIA PURA DO DIREITO

A força de Nuremberg como precedente não é evidente em julgamentos internacionais meio século depois. No entanto, o verdadeiro legado de Nuremberg foi a constituição da abordagem dominante para a injustiça do Estado. ${ }^{110}$

Toda a divergência relacionada ao Tribunal de Nuremberg leva, portanto, ao questionamento sobre a existência ou não de uma carga política incorporada aos julgamentos. Resta ainda a indagação a respeito do que efetivamente se buscou com esses precedentes, já que o discurso oficial era o de "justiça" e "combate à impunidade", mas o que ficou evidente a partir da crítica elaborada por Kelsen foi a ausência de um marco divisório apto a separar o direito das questões políticas - maior preocupação teórica de Kelsen ao longo de toda sua carreira como teórico do direito. Sua intenção era justamente impedir que o direito fosse instrumentalizado por argumentos ou poderes políticos particulares em um contexto histórico de crise do parlamentarismo europeu nas primeiras décadas do século XX. Afastar a instrumentalização política das ciências jurídicas foi, portanto, o objetivo primordial da TPD, daí a sua ideia de uma teoria "puramente jurídica do direito", cujos fundamentos fossem única e exclusivamente oriundos da lógica inerente ao universo normativo, uma ordem vinculada ao sollen (dever ser) e não ao sein (ser), àquilo que realmente existe/é.

\section{CONCLUSÃO}

A “Fórmula de Radbruch" é considerada um verdadeiro marco da ciência do direito dentro do contexto de ascensão das discussões sobre direitos humanos, que avançaram com os julgamentos de Nuremberg e a subsequente Declaração Universal dos Direitos do Homem, aprovada pela Assembleia Geral da ONU em 1948. ${ }^{111}$ Nos processos de Nuremberg prevaleceu o entendimento a respeito da rejeição da legalidade do regime nazista, com o fundamento em dois pontos: o primeiro deles considerou que as normas jurídicas que contrariam o "sentimento de humanidade" e de "justiça” não possuem validade jurídica. ${ }^{112} 0$ segundo raciocínio, fortemente apoiado pelos Aliados, que ocupavam a Alemanha na ocasião, foi o de que os tribunais nacionais e internacionais devem julgar atos considerados como graves violações de direitos humanos. ${ }^{113}$ Os

\footnotetext{
110 "The strength of Nuremberg as precedent is not evident in international trials a half-century later. Nevertheless, Nuremberg's real legacy is that it spawned the dominant approach to state injustice". TEITEL, 1997, 2039.

111 SWENSSON JUNIOR, 2010, p. 49.

112 DIMOULIS, 2010, p. 115.

113 Ibidem.
} 
processos tornaram-se possíveis com base na criação de leis penais que retroagiriam no caso particular das violações de direitos humanos, visto que tais crimes (contra a humanidade) foram considerados como imprescritíveis.

Um dos Estados que aboliu o princípio da legalidade em nome de critérios moraisteológicos, travestidos de conceito políticos, foi a própria Alemanha nazista. A concepção de direito utilizada para legitimar o regime nacional-socialista não foi a de Kelsen, mas a de seus contemporâneos Karl Larenz e, sobretudo, Carl Schmitt. Ao contrário de Kelsen, que via no Tribunal Constitucional o papel de guardião da constituição, sem quaisquer poderes executivos e apenas intitulado à uma "legislação negativa”, a teoria de Schmitt da soberania está baseada em critérios teológicos-políticos e numa concepção do soberano como "guardião da constituição". A sua teoria dos “ordenamentos concretos" também foi outro constructo adotado pelos nacionalsocialistas. Por outro lado, as teorias "antipositivistas", ou “decisionistas"114, de autores como Carl Schmitt e Karl Larenz, pregavam a livre reinterpretação do direito em favor dos valores e das necessidades do “povo" e da “nação” alemã, estando fortemente calcadas em critérios de validade teológico-políticos secularizados, tal como teorizara Schmitt. Desde que tais interpretações-decisões estivessem pautadas pelos os desígnios daquele que detém a soberania política, ou seja, o comando político sobre o executivo, elas seriam consideradas normas/decisões válidas. Para Schmitt,

o direito não se baseava nem em normas positivas, nem em sentenças transitadas em julgado nos tribunais: ou seja, não era nem normativo, nem decisionismo. 0 direito nascia dos 'ordenamentos concretos' (konkrete Ordnungen) da vida social. Sob um novo nome retornava assim a teoria da gênese social, e não estatal, do direito. Por 'ordenamento concreto' Schmitt entende efetivamente (...) a realidade social do nacional-socialismo. ${ }^{115}$

A “Fórmula de Radbruch" teve como desfecho a criação de um tribunal ad hoc erigido pelos vencedores da guerra (os Aliados), o que efetivamente violou os princípios consagrados pelo direito penal da legalidade e do juiz natural em razão do julgamento de fatos prévios à criação do Tribunal, o que pode ser considerado como um julgamento de exceção. Outro ponto a se levantar é que um dos Estados que ignorou o princípio da legalidade conforme as posições políticoideológicas do regime nazista foi própria Alemanha, visto que as ordens de prisão eram sumárias, permitindo-se a retroatividade de incriminações e tipificações por analogia, algo completamente

\footnotetext{
114 SWENSSON JUNIOR, op.cit., p. 48.

115 LOSANO, 2010, p. 212-213.
} 
contrário aos padrões aceitos pelo processo penal já naquela época. ${ }^{116}$ Não obstante as críticas formuladas por Hans Kelsen, a formação do Tribunal de Nuremberg foi a solução que viabilizou os julgamentos, respeitando-se os princípios formais básicos do Estado de Direito, tais como o devido processo legal (due process of law) e as garantias dele decorrentes, apesar das claras motivações políticas presentes por detrás das intenções dos vencedores da guerra com os processos.

Por fim, os argumentos jurídicos utilizadas pelo regime nacional-socialista para prover fundamentação legal a seus atos foram diametralmente opostos, tal como se argumentou acima, aos argumentos da TPD. Muito pelo contrário, trataram-se de concepções defendidas por seus maiores opositores no campo da teoria jurídica, em especial as teses sobre "soberania" e sobre direito de Carl Schmitt. Dessa forma, as acusações de que a TPD teria compactuado com o regime e os crimes nazistas não estão respaldadas nem pela história nem pela teoria. Essa acusação, conforme defendido neste ensaio, confunde os requisitos de validade da norma com os requisitos de validade do sistema jurídico.

\section{REFERÊNCIAS}

ARENDT, Hannah. Eichmann em Jerusalém. Um relato sobre a banalidade do mal. Tradução José Rubens Siqueira. São Paulo: Companhia das Letras, 1999.

ARENDT, Hannah. Origens do totalitarismo. Antisemitismo, imperialismo e totalitarismo. Tradução Roberto Raposo. 10 ${ }^{a}$ reimpressão. São Paulo: Companhia das Letras, 2012.

AGAMBEN, Giorgio. Estado de Exceção. São Paulo: Boitempo, 2004.

BARCELLOS, Ana Paula de. Ponderação, racionalidade e atividade jurisdicional. Rio de Janeiro: Renovar, 2005

BATISTA, Nilo. Introdução Crítica ao Direito Penal. Rio de Janeiro: Revan, 2003.

BORRMANN, Ricardo Gaulia. Hans Kelsen and the Austrian Constitutional Court: family law, political conciliation and religious culture (1919-1930). Sociologia del diritto n. 3, 2014, p. 6591. Disponível em: https: //dialnet.unirioja.es/servlet/articulo?codigo=5086964. Acesso em 11 nov. 2020.

BORRMANN, Ricardo G. A recepção de Hans Kelsen na Constituinte de 1933-34: Entre Positivismo Jurídico e Neotomismo. In: NEDER, Gizlene; SILVA, Ana Paula Barcelos Ribeiro da Silva; SOUZA, Jessie Jane Vieira de (orgs.). Intolerância e Cidadania: secularização, poder e cultura política. Rio de Janeiro: Autografia, 2015, p. 396-421.

${ }^{116}$ GODOY, 2017, p. 1. 
CERQUEIRA FILHO, Gisálio. Autoritarismo Afetivo: a Prússia como sentimento. São Paulo: Escuta, 2005.

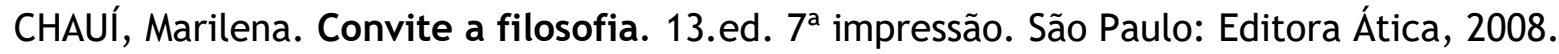

DIMOULIS, Dimitri. Justiça de transição e função anistiante no Brasil. Hiposiações indevidas e caminhos de responsabilização. In: DIMITRI, Demoulis; MARTINS, Antonio; SWENSSON JUNIOR, Lauro Joppert (Orgs). Justiça de Transição no Brasil. São Paulo: Saraiva, 2010, p. 91-128.

CRUZ, Eugeniusz. Justiça de transição no Brasil: análise crítica da persecução penal dos agentes da ditadura. Curitiba: Juruá, 2015.

DIMOULIS, Dimitri. Positivismo jurídico e senso comum. In: Idem (org.). A Relevância Prática da Teoria do Direito. Belo Horizonte: Arraes editores, 2016.

GELLATELY, Robert. Os marginais sociais e a consolidação da ditadura de Hitler, 1933-1939. Tradução Beatriz Medina. In: ROLLEMBERG, Denise; QUADRAT, Samantha Viz (Orgs.) Construção Social dos Regimes Autoritários. Legitimidade, consenso e consentimento no século XX Europa. Rio de Janeiro: Civilização Brasileira, 2010.

GODOY, Arnaldo Sampaio de Moraes. O nacional-socialismo e a equivocada imputação de culpa alemã no contexto das críticas ao positivismo: notas em defesa de Hans Kelsen. In: BORGES, Ivan Cláudio Pereira (org.) A Teoria Jurídica de Hans Kelsen. Rio de Janeiro: Lumen Juris, 2017, p.117.

HAFFNER, Sebastian. Geschichte eines Deutschen. Als Engländer maskiert. München: Deutsche Verlags-Anstalt, 2006.

HALDEMANN, Frank. Gustav Radbruch v. Hans Kelsen: um debate sobre o Direito Nazista. In: FARO, Julio Pinheiro e BUSSINGER, Elda Coelho (org.). A diversidade do pensamento de Hans Kelsen. Rio de Janeiro: Lumen Juris, p. 275-294.

HOBSBAWN, Eric. Era dos Extremos. O breve século XX 1914-1991. Tradução Marcos Santa Rita; revisão técnica Maria Célia Paoli. 2. ed. $44^{a}$ reimpressão. São Paulo: Companhia das Letras, 1995.

HOFFMANN, Fábio; LEITE, Fábio Carvalho. Die Wirkung der Weimarer Verfassung: ein Blick nach Brasilien. Kritische Justiz, Vol. 52 (2019), Issue 3, p. 265-279. DOI:

https://doi.org/10.5771/0023-4834-2019-3.

JABLONER, Clemens. Kelsen and his circle: The Viennese years. European Journal of International Law 9 (1998), 368-385.

JAPIASSÚ, Hilton. O mito da neutralidade científica. Rio de Janeiro: Imago Editora, 1975.

JAPIASSÚ, Hilton. Introdução ao pensamento epistemológico. $2^{\mathrm{a}}$ ed. Rio de Janeiro: F. Alves, 1977.

JAPIASSÚ, Carlos Eduardo Adriano. O Tribunal Penal Internacional. A internacionalização do direito penal. Rio de Janeiro: Lúmen Juris, 2004. 
KELSEN, Hans. Will the judgement in Nuremberg Trial constitute a precedent international Law?. The International Law Quarterly. Vol.1, n² 2, Cambridge University press, Summer 1947.

KELSEN, Hans. Wer soll der Hüter der Verfassung sein?. In: KLECATSKY, Hans; MARCIC, René; SCHAMBECK, Herbert (org.). Die Wiener Rechtstheoretische Schule. Wien: Europa Verlag, 1968, p. $1873-1922$.

KELSEN, Hans. Prefácio à primeira edição. In: Idem. Teoria Pura do Direito. São Paulo: Martins Fontes, 2009, p. XI-XV.

KELSEN, Hans. Autobiografia de Hans Kelsen. Rio de Janeiro: Universitária, 2011.

KELSEN, Hans. Teoria Pura do Direito. 9. ed. revista da tradução de J. Cretella Jr. e Agnes Cretella. São Paulo, Revista dos Tribunais, 2013.

LOSANO, Mario G. Presenças italianas em Kelsen. In: KELSEN, Hans. Direito internacional e Estado soberano. São Paulo: Martins Fontes, 2002, p. 1-76.

LOSANO, Mario G. Sistema e estrutura no direito, volume 2: o Século XX. São Paulo: Martins Fontes, 2010.

MEIER, Heinrich. Carl Schmitt, Leo Strauss y El concepto de lo político. Sobre un diálogo entre ausentes. Buenos Aires: Katz, 2008.

MÉTALL, Rudolf Aladár. Hans Kelsen. Leben und Werk. Wien: Franz Deuticke, 1968.

NEDER, Gizlene; CERQUEIRA FILHO, Gisálio. Criminologia e Poder Político. Sobre Direitos, História e Ideologia. Rio de Janeiro: Lumen Juris, 2006.

NEDER, Gizlene. Idéias jurídicas e autoridade na família. Rio de Janeiro: Revan, 2007.

OHLIN, Jens David. On the Very Idea of Transitional Justice. The Whitehead Journal of Diplomacy and International Relations, Vol. 8, No. 1, pp. 51-68, 2007. Social Science Research Network (SSRN). Disponível em: https: //ssrn.com/abstract=1263347. Acesso em: 20 nov. 2019.

OLECHOWSKI, Thomas. Hans Kelsen. Biographie eines Rechtswissenschaftlers. Tübingen: Mohr Siebeck, 2020.

RIBEIRO, Fernando José Armando. Entre a continuidade e ruptura: Revolução e formalismo no direito moderno. Revista do Instituto de Hermenêutica Jurídica. Vol.8, n.8, (2010). Belo Horizonte, p. 81/98.

SCHMITT, Carl. Der Begriff des Politischen. Berlin: Duncker \& Humblot, 2015.

SCHMITT, Carl. Der Huiter der Verfassung. Berlin: Duncker \& Humblot, 2016.

SCHORSKE, Carl. Pensando com a história: indagações na passagem para o modernismo. São Paulo: Companhia das Letras, 2000. 
SCHULMEISTER-ANDRÉ, Irina. Internationale Strafgerichtsbarkeit unter sowjetischem Einfluss. Der Beitrag der UdSSR zum Nürnberger Hauptkriegsverbrecherprozess. Berlin: Duncker \& Humboldt, 2016.

SHIRER, William L. Ascensão e Queda do Terceiro Reich, volume I. Rio de Janeiro: Editora Civilização Brasileira S.A., 1962.

SOUZA, Ricardo Luiz. Hannah Arendt e o totalitarismo: o conceito e os mortos. Revista Ética \& Filosofia Política (Volume 9, número 1, junho/2006). Disponível em: http://periodicos.uesb.br/index.php/politeia/article/viewFile/230/248. Acesso em: $01 \mathrm{dez}$. 2019.

STRECK, Lênio Luiz. Verdade e consenso: constituição, hermenêutica e teorias discursivas. São Paulo: Saraiva, 2012

SWENSSON JUNIOR, Lauro Joppert. Punição para os crimes da ditadura militar. Contornos do debate. In: DIMITRI, Demoulis; MARTINS, Antonio; SWENSSON JUNIOR, Lauro Joppert (Orgs.) Justiça de Transição no Brasil. São Paulo: Saraiva, 2010, p. 23-60.

TEITEL, Ruti. Transitional jurisprudence: the role of law in political transformation. Yale Law Journal. Vol. 106, No. 7 (May, 1997), p. 2009-2080. Disponível em:

https://www.jstor.org/stable/797160. Acesso em: 11 nov. 2020.

TEITEL, Ruti. Transitional Justice Genealogy. Harvard Human Rights Journal. Vol. 16, 2003. Disponivel em: https://www.qub.ac.uk/Research/GRI/mitchellinstitute/FileStore/Filetoupload,697310,en.pdf. Acesso em: 11 nov. 2020.

VASCONCELOS, Arnaldo. Teoria Pura do Direito: repasse crítico de seus principais fundamentos. $2^{\mathrm{a}}$ ed., Rio de Janeiro: GZ, 2010.

ZAFFARONI, Eugenio Raul; BATISTA, Nilo; ALAGIA, Alejandro; SLOKAR, Alejandro. Direito Penal Brasileiro - vol.I. 4. Ed. Rio de Janeiro: Revan, 2011.

Recebido em: 18.11.2020 / Aprovado em: 22.04.2021 / Publicado em: 06.05.2021

\section{COMO FAZER REFERÊNCIA AO ARTIGO (ABNT):}

BORRMANN, Ricardo; Cruz, EUGENIUSZ. O Tribunal de Nuremberg e a teoria pura do direito. Revista

Eletrônica do Curso de Direito da UFSM, Santa Maria, RS, v. 15, n. 2, e63122, maio/ago. 2020. ISSN 19813694. DOI: http://dx.doi.org/10.5902/1981369463122. Disponível em:

https://periodicos.ufsm.br/revistadireito/article/view/63122 Acesso em: dia mês. ano.

Direitos autorais 2020 Revista Eletrônica do Curso de Direito da UFSM

Editores responsáveis: Rafael Santos de Oliveira e Angela Araujo da Silveira Espindola

Esta obra está licenciada com uma Licença Creative Commons Atribuição-NãoComercial-SemDerivações 4.0 Internacional. 


\section{SOBRE OS AUTORES}

\section{RICARDO BORRMANN}

Doutor em História Cultural pela Faculdade de Letras e Ciências Linguísticas da Universidade de Munique (Ludwig-Maximilians-Universität München, LMU). Mestre em Teoria Política pela Universidade Federal Fluminense (UFF, 2009) e Bacharel em Ciências Sociais pela Universidade Federal do Rio de Janeiro (UFRJ, 2007). Atualmente trabalha como docente e pesquisador pós-doc. (Habilitation) na Cátedra de História da América Latina do Departamento de História da Universidade de Bremen (Alemanha). Seu projeto de pesquisa de pós-doutorado trata da reconstrução da rede intelectual transnacional e latino-americana de Paulo Emílio Salles Gomes. Intitulado Latin America, film culture and transatlantic exchanges: the intellectual network of Brazilian film critic Paulo Emílio Salles Gomes (1935-1977) o projeto conta com financiamento da Zentrale Forschungsförderung (Central Research Development Fund, CRDF) da Universidade de Bremen para jovens doutores-pesquisadores. Coordena juntamente com a Profa. Delia González de Reufels (Cátedra de História da América Latina) o projeto Win a Tutor: Didaktische E-Learning-Anwendungsszenarien, junto ao Zentrum für Multimedia in der Lehre (ZMML), para o uso de novas tecnologias digitais e de vídeo explicativos no ensino da história. Atua como coordenador do Programa Erasmus no Departamento de História da Universidade de Bremen e é Pesquisador Associado ao Laboratório Cidade e Poder (LCP/UFF). Atuou como Assistente de Pesquisa no LCP e como Assistente Editorial de Passagens-Revista Internacional de História Política e Cultura Jurídica (CAPES A2). Faz parte do Conselho Editorial da referida Revista e ainda da Revista Direito em Movimento. É membro-sócio da Associação Nacional de Pesquisa Universitária em História (ANPUH) desde 2009 e da Latin American Studies Association (LASA). Atua nas áreas de Estudos Culturais, Intelectuais de fala alemã, Recepção transatlântica de ideias, História Intelectual Moderna e Contemporânea, Intelectuais e Cinema, com ênfase nos seguintes eixos temáticos: pós-colonialismo e práticas de decolonização, redes intelectuais transatlânticas, cultura de língua alemã, cinema e mídia, memória, pensamento jurídico, racismo e eugenia, intelectuais e exílio. Pesquisou sobre a recepção de autores de língua alemã pelos intelectuais brasileiros da Escola do Recife Tobias Barreto e Sílvio Romero. Sua tese de doutorado sobre o tema intitulase Tobias Barreto, Sílvio Romero und die Deutschen. Die Rezeption deutschsprachiger Autoren in der brasilianischen Rechtskultur (1869-1889) e foi publicada pela editora Franz Steiner (Stuttgart) em 2019.

\section{EUGENIUSZ CRUZ}

Doutorando pela Universidade Federal Fluminense no programa de Pós graduação em Sociologia e Direito (PPGSD-UFF); Integrante do grupo de pesquisas: Laboratório Cidade e Poder, coordenado pela professora doutora Gizlene Neder, vinculado a Universidade Federal Fluminense (UFF); Associado ao Instituto Brasileiro de Ciências Criminais (IBCCRIM); Mestre em Direito Público pela UNESA (CAPES 5), tendo realizado a sua pesquisa como bolsista da CAPES; foi coordenador do curso de Direito do campus Duque de Caxias nos anos de 2014, 2015 e 2016; Professor de Direito Penal e Processual Penal na Graduação e Pós-Graduação latu sensu da UNESA. Possui interesse nas áreas de Direito Penal, Processo Penal, Criminologia, História do Direito,Teoria Crítica, Justiça de Transição, Política de Drogas, Direitos Humanos e Metodologia da Pesquisa. É bolsista do Programa Produtividade da Universidade Estácio de Sá. 